\title{
Employment of doctors of veterinary medicine from 2010 - 2019
}

\author{
D. Cvitkovic ${ }^{*}$, B. Volarević, M. Tadić, S. Pašić and M. Pavlak
}

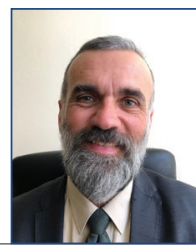

\begin{abstract}
The employment of veterinarians is an indicator of economic development and of the quality of the relationship between humans and nature. Several authors have published reports on the employment of veterinarians. This paper examines the trends in unemployment and employment of veterinarians according to the records of the Croatian Employment Service (CES) in the period from 2010 to 2019. The CES is a public institution of the Republic of Croatia established under the Labour Market Act (Official Gazette 118/18) that plays a key role in regulating supply and demand on the labour market of the Republic of Croatia. The average number of employed veterinarians was higher than the average number of veterinarians registered in the CES records. An average of 181 veterinarians were sought annually, 160 were employed and 143 were registered, indicating that demand surpassed supply. Veterinarians were recruited faster than the average person with a college degree, within 180 days, and very few were in longterm unemployment. Most were employed in the category of young people (up to 30 years of age), and most were employed without any previous work experience. More women than men were employed. Most veterinarians were
\end{abstract}

employed in the City of Zagreb, which reflects the relatively low livestock production and depopulation of rural areas, as the traditionally main and safest source of employment for veterinarians. According to the National Classification of Economic Activities (NKD), veterinarians were employed in almost all groups of activities, allowing for greater employment flexibility and mobility on the labour market. According to the National Classification of Occupations (NKZ), on the other hand, most veterinarians were employed in group 2 (experts and scientists), likely since veterinary medicine is a regulated profession. This also means that several were employed under their qualification levels. The employment of veterinarians was relatively better than for other university-educated workers, due to the relatively higher number of registered vacancies. The regression equation showed that the number of jobs offered to veterinarians in the observed period increased by slightly more than 9 jobs per year, indicating a possible increase in demand for veterinarians in the future. The same trend is seen in the projection of future trends in the labour market, which predicted an increase in the number of employed veterinarians in the period from 2014 to 2020 , as well as an

Denis CVITKOVIĆ*, DVM, PhD, Assistant Professor, Faculty of Veterinary Medicine, University of Zagreb, Croatia, (Corresponding author, e-mail: denis.cvitkovic@vef.hr); Boris VOLAREVIĆ, BSc, Croatian Employment Service, RO Sisak, Sisak, Croatia; Marko TADIĆ, DVM, PhD, Retired Full Professor; Selim PAŠIĆ, BSc Phys, PhD, Assistant Professor, Marina PAVLAK, DVM, PhD, Full Professor, Faculty of Veterinary Medicine, University of Zagreb, Croatia 
increase in the number of retirements. The data imply that it is necessary to increase the number of veterinarians, but also to raise their competencies to meet the increased competition on the European and global labour markets.

Key words: labour market; veterinarians; increased employment

\section{Introduction}

The problem of aligning the education system with the needs of the labour market has existed for decades. Inadequate enrolment policy is one of the generators of unemployment, and it is taking on a new dimension thanks to the demographic exodus that has gripped Croatia following EU accession and liberalization of the European labour market. "Unemployment in Croatia is a consequence of the lack of structural changes in the economy. The destruction of jobs in the context of liquidations and bankruptcies of a large number of companies was not accompanied by the creation of a sufficient number of new jobs in the private sector. Relatively high real wages and salaries, institutional inflexibility and general mismatch between labour supply and demand seem to be the biggest obstacles to a more dynamic labour market" (Anonymous, 2007). Employment and the contribution of individuals to the economy is one of the fundamental visions upon which the Education, Science and Technology Strategy (Official Gazette 124/14) and the Croatian Qualifications Framework (Official Gazette 22/13, 41/16, 64/18) were founded.

Animals and their health have been an indispensable part of civilization throughout history, and significantly contribute to increased quality of life (Zavrtnik and Žubčić, 2017a,b,c,d; 2018; Cvetnić, 2019; Džaja and Severin, 2019a,b; Gregurić Gračner et al., 2019; Mraović et al., 2019). The employment of veterinarians is an indicator of economic development and of the quality of the relationship between humans and nature.
Tadić et al. (2006, 2009, 2012, 2013 and 2016) and Cvitković et al. (2020) published reports on the employment of veterinarians. This paper analyses the trendsin unemployment and employment of veterinarians according to the records of the Croatian Employment Service (CES) in the period from 2010 to 2019. CES is a public institution of the Republic of Croatia established under the Labour Market Act (Official Gazette 118/18) and it plays a key role in regulating supply and demand on the labour market of the Republic of Croatia.

Pursuant to the Labour Market Act (Official Gazette 118/18), an unemployed person is someone fully or partially capable to work, aged 15 to 65 years, who is not employed or self-employed, and who is actively looking for and is available for work.

A doctor of veterinary medicine (veterinarian) can be viewed as both an occupation (Official Gazette 111/98) and as a profession (Official Gazette 105/01). An occupation is defined as a set of jobs and work tasks that are similar in content and type, organizationally and technologically related and interconnected so that they are performed by one executor who possesses the appropriate knowledge, abilities and skills. A profession, on the other hand, is a set of knowledge and skills acquired by mastering a certain curriculum. In this paper, we use the notion of profession, except in the part related to vacancies.

Insight into the demand for veterinarians was obtained by monitoring employment from the records of the Croatian Employment Service (CES) 
and data on vacancies. Registration of vacancies is not mandatory; hence a part of the demand is not registered in the CES and therefore employment is not registered. The title of Doctor of Veterinary Medicine in Croatia is acquired exclusively at the Faculty of Veterinary Medicine, University of Zagreb (VEF). The study programme lasts 6 years and requires the completion of a minimum of 360 ECTS credits (Anonymous, 2020d).

\section{Materials and methods}

Data were collected from the publicly available CES database (Anonymous, 2020a). A database for the number and structure of unemployed was also used through the internal information system available to CES employees who perform tasks related to the analysis and statistics of unemployment and employment. Part of the data was acquired from the website of the Central Bureau of Statistics (Anonymous, 2020b). Data from the CROQF (Croatian Qualifications Framework) portal were also used (Anonymous, 2020c). Data were processed by appropriate statistical methods using STATA 14 and Excel programs.

\section{Results}

Employment of veterinarians refers to persons from the records of the Croatian Employment Service (CES) who were employed either in a full-time position, or on the basis of other business activities. On average, 160 veterinarians were employed annually in the observed period (a total of 1,598) in Croatia. According to the CBS, an average of 81 students graduated from VEF annually in the period 2010-2017. The number of employed veterinarians increased by 56 persons or 33.9\% between 2010 and 2013, then stagnated until 2018 when it dropped to 139 persons, and increased again in 2019. Compared to 2010, the number of employed veterinarians in 2019 was $25 \%$ higher at 152 . The average number of unemployed veterinarians per year in the observed period was 143 .

In Croatia, the number of all employed persons with a university degree increased by 59.5\% from 2010 to 2015 , and then decreased in 2019 by $23.6 \%$ compared to 2015. The employment dynamics of veterinarians differs from this pattern and is shown in Figure 1.

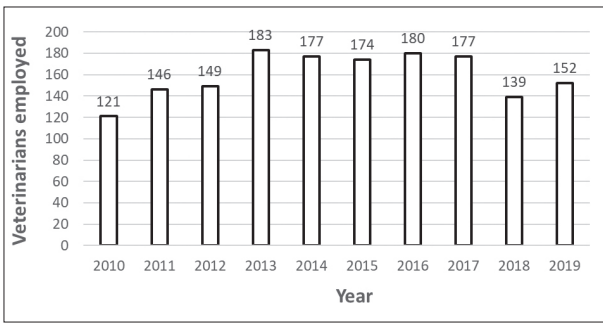

Fig. 1. Veterinarians employed (2010-2019) (Source: CES - Croatian Employment Service, author's calculation)

According to age (Fig. 2), most employed veterinarians were aged 2529 years, accounting for $39.5 \%$ of the sample. This age group had a higher proportion $(49.7 \%)$ of employment in the total employment of all persons with a university degree in Croatia. Young people (15 to 29 years old) accounted for $40.4 \%$ of the total employment of veterinarians, and for $59.6 \%$ of all persons holding a university degree, which is almost 20 percentage points more. Middle-aged persons (30 to 49 years of age) accounted for $44.7 \%$ of the employment of veterinarians, while the majority of employment was in the age group of 30 to 34 years. This share was lower (35.6\%) amongst the total persons holding a university degree. Among veterinarians, the share of employment of persons older than 50 years was $14.9 \%$, as compared to $4.7 \%$ among all those with a university diploma in Croatia. 


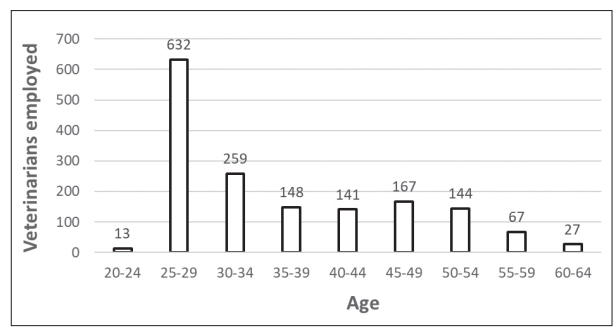

Fig. 2. Veterinarians employed by age (20102019) (Source: CES - Croatian Employment Service, author's calculation)

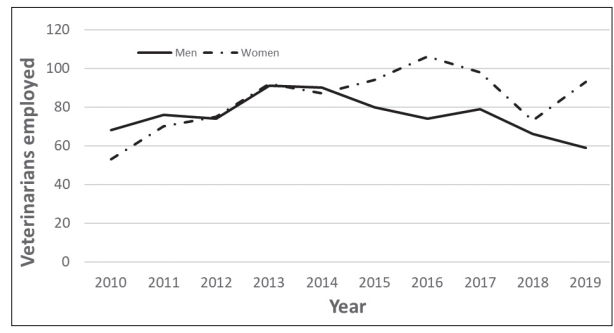

Fig. 3. Veterinarians employed by gender (20102019) (Source: CES - Croatian Employment Service, author's calculation)

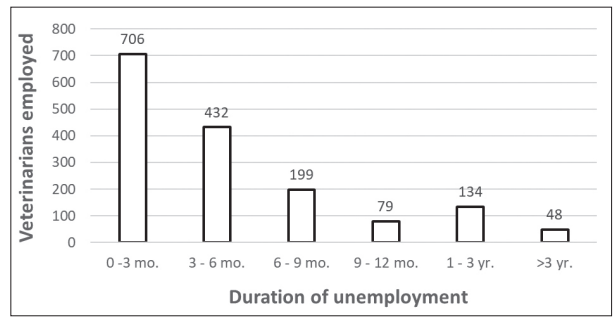

Fig. 4. Veterinarians employed by duration of unemployment (2010-2019) (Source: CES - Croatian Employment Service, author's calculation)
Female veterinarians were employed slightly more than male veterinarians. In the total number of employed veterinarians, $52.6 \%$ were female and $47.4 \%$ were male. In 2014 , the number of employed males dropped. The number of employed females rose until 2016, then fell sharply in 2018, and rose sharply again in 2019 (Fig. 3). Among all those with a university degree in Croatia, $69.3 \%$ were female and $30.7 \%$ were male. In Croatia, significantly more university-educated women were employed, which is not the case with veterinarians. Annual changes in employment by gender are less pronounced among all persons with a college degree than among veterinarians. According to the Central Bureau of Statistics (CBS), a total of 254 males (39.26\%) and 393 females (60.74\%) graduated from VEF in the period from 2010 to 2017. On average, 32 men and 49 women graduated annually (81 in total).

A higher level of education is generally associated with faster employment. Upon completion of their studies, veterinarians were hired relatively quickly, so that as many as $71.2 \%$ (1138) found a job within 180 days (Fig. 4). Within one year, the employment rate was $88.6 \%$. This was virtually the same rate amongst all persons with a college degree in Croatia. The issue of long-term unemployment (longer than one year) was not prominent among veterinarians.

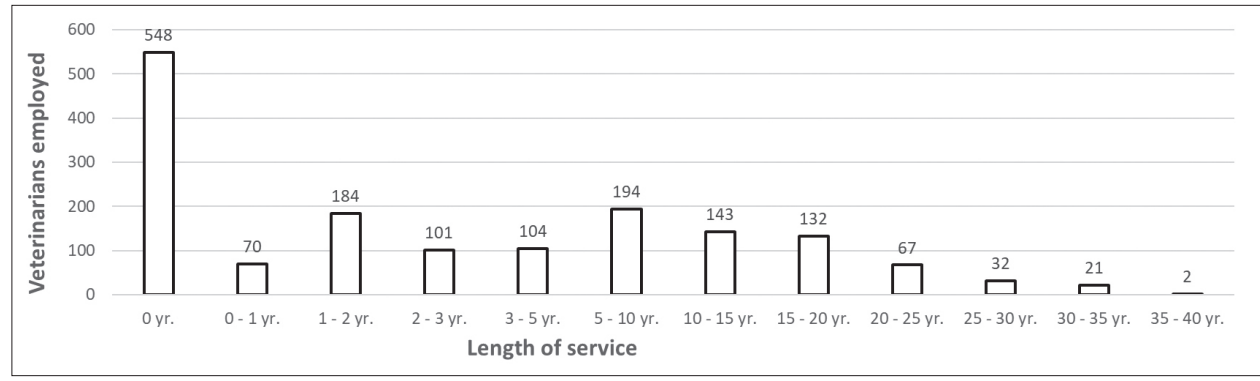

Fig. 5. Veterinarians employed by length of service (2010-2019) (Source: CES - Croatian Employment Service, author's calculation) 
Young veterinarians were hired fairly quickly. Mostly employed were those without work experience, those with 1 to 2 years of experience and those with 5 to 10 years of experience (Fig. 5). About one third of employed veterinarians were persons without work experience, which was similar amongst all college degree holders, where the share was $30.4 \%$. Work experience is not a very limiting factor in the employment of veterinarians as is the case in some other higher education professions.

Veterinarians are predominantly employed in the City of Zagreb (40.4\%) and Zagreb County (7.9\%) (Fig. 6). Thus, almost half of them $(48.3 \%)$ are employed in the Zagreb area. The lowest employment was in Lika-Senj County, with only four people $(0.3 \%)$ employed in 10 years.

More than two-fifths of all veterinarians were employed in the City of Zagreb, though less than a quarter $(23.8 \%)$ of all persons with a university degree in Croatia were employed there.

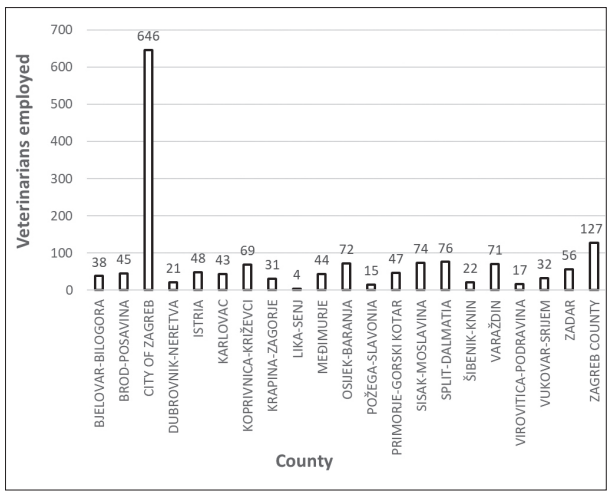

Fig. 6. Veterinarians employed by county (20102019) (Source: CES - Croatian Employment Service, author's calculation]

According to the groups of activities listed in the National Classification of All Economic Activities (NKD in Croatian), veterinarians were employed in 18 of the 22 groups (groups from A to U) (Official Gazette 98/94). Most veterinarians (46.6\%) were employed in the activities of group $\mathrm{M}$ (professional, scientific and technical activities), followed by $18.7 \%$ in the

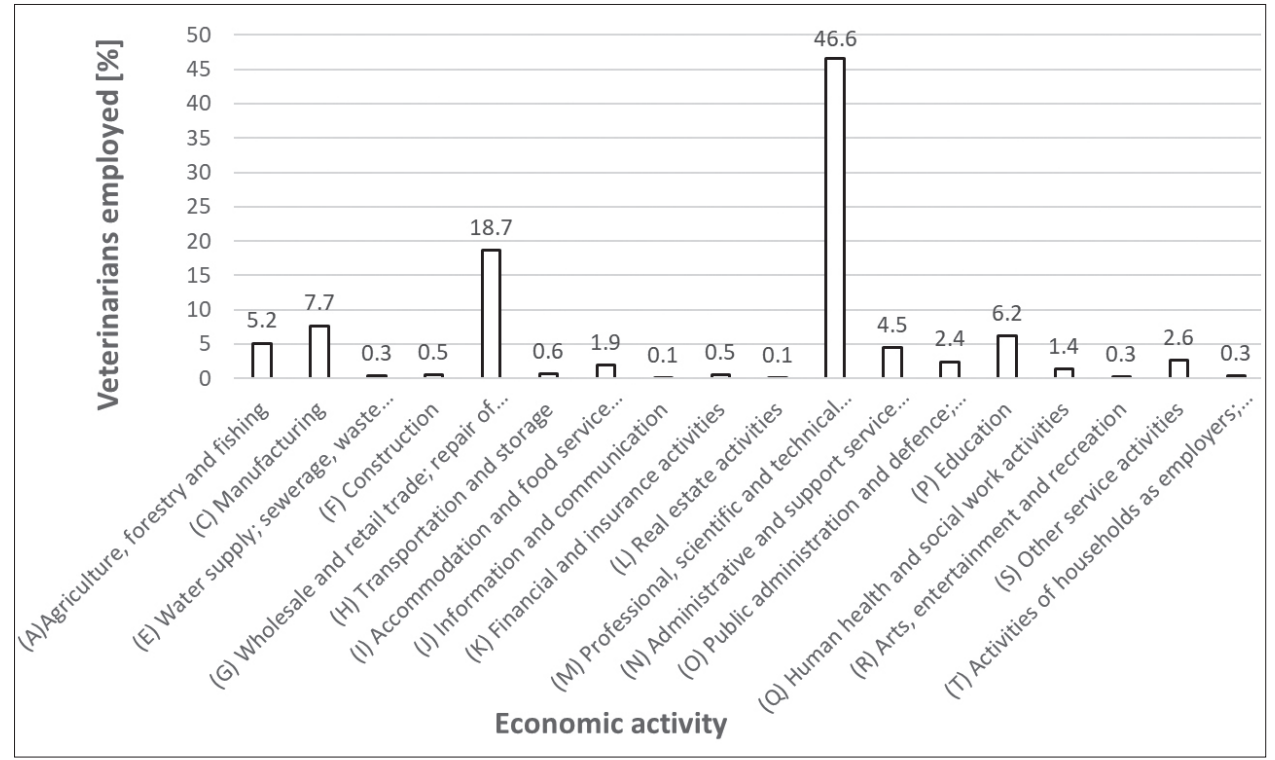

Fig. 7. Veterinarians employed by the National Classification of All Economic Activities for 2010-2019 (NKD 2007) (Source: CES - Croatian Employment Service, author's calculation) 
activities of group $\mathrm{G}$ (wholesale and retail trade), $7.7 \%$ in group C (manufacturing industry), and $6.2 \%$ in group $\mathrm{P}$ (education) (Fig. 7). Among all persons with a university degree in Croatia, the majority $(30.6 \%)$ were employed in the activities of group P (education) and $9.0 \%$ in group $\mathrm{M}$ (professional, scientific and technical activities).

The National Classification of Occupations from 1998 (NKZ 98) defines 10 occupation groups, and the group code is contained in the first digit of the occupation code. The importance of occupations is that they clarify the type of work within the occupation and the level of knowledge and skills needed to work effectively in the workplace. By occupation, more than three quarters of veterinarians were employed in group 2 (experts and scientists), followed by $8.4 \%$ in group 3 (engineers, technicians and related professions), $6.0 \%$ in group 5 (service and trade occupations), etc. (Fig. 8). Among all persons with a university degree in Croatia, 51.8\% were employed in group 2 (experts and scientists), and $17.4 \%$ in group 3 (engineers, technicians and related occupations).

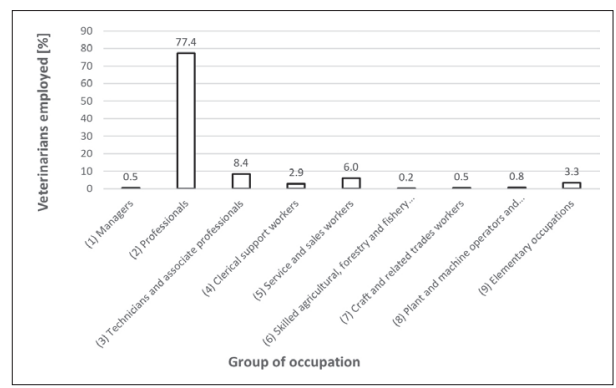

Fig. 8. Veterinarians employed according to the National Classification of Occupations in 2010-2019 (NKZ 98) (Source: CES - Croatian Employment Service, author's calculation)

Two types of employment are possible: fixed-term and permanent. About 65\% of veterinarians were employed on a fixed-term basis, as compared to $76.4 \%$ of all persons with a university degree in Croatia.

Of the total of $1,521,758$ employed persons in Croatia at the end of November $2019,372,758$ persons $(24.50 \%)$ had a fixed-term employment contract, and $1,149,000$ persons $(75.50 \%)$ had a permanent contract. The proportion of fixed-term contracts was twice as high as the EU average and this form of work is expanding more quickly in Croatia than in any other EU country.

Demand for workers can be monitored by monitoring vacancies that employers report to the Croatian Employment Service, and which relate to employment on the basis of a full-time position or based on other business activities. The data are presented according to the place of the need for a worker (by county) and according to the place where the worker will work (county or abroad). The number of required workers annually represents the sum of the number of required workers by month in the respective year. As a rule, vacancies are advertised on the CES website, and also on its bulletin boards.

In the observed period, the total number of vacancies for veterinarians was 1,811 with an annual average increasing trend (Fig. 9). In the regression equation, the data are fitted to a line, and the value of slope $a$ of the line ( $a=9.2)$ shows that the rate of new registered vacancies was 9.2 per year. Such growth could be

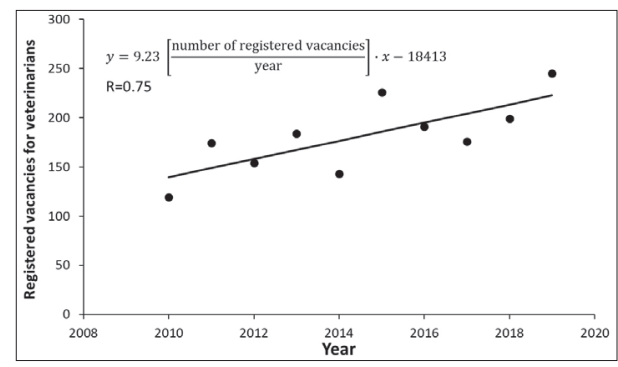

Fig. 9. Registered vacancies for veterinarians (2010-2019) (Source: CES - Croatian Employment Service, author's calculation) 
expected in following years. On average, 181 veterinarians were sought annually.

The average number of veterinarians registered with the CES per year in the observed period was 143 . The demand for veterinarians was $26.6 \%$ higher than the supply, and this demand increased during 2018 and 2019. The number of registered vacancies in 2019 was twice as high as in 2010, with 126 more veterinarians sought. In 2018 and 2019, demand was significantly higher than employment. There was a slight shortage of veterinarians on the labour market due to increased retirement and work abroad. According to the data of the Institute of Economics in Zagreb, in the sector of agriculture, food and veterinary medicine, a significant exit from the labour force is expected in the coming years (Table 1) (Anonymous, 2015). During the study period, it is estimated that $16 \%$ of the working population left Croatia, while at the same time only 3\% left the Czech Republic and about 4\% left Slovenia.

Table 1. Veterinary occupation employees by type of retirement learly retirement or old-age pension) (Anonymous, 2015).

\begin{tabular}{|c|c|c|c|}
\hline Year & Early & Old-age & Total \\
\hline 2014 & 295 & 78 & 373 \\
\hline 2015 & 44 & 37 & 81 \\
\hline 2016 & 42 & 32 & 74 \\
\hline 2017 & 49 & 31 & 80 \\
\hline 2018 & 52 & 49 & 101 \\
\hline 2019 & 79 & 51 & 130 \\
\hline 2020 & 87 & 42 & 129 \\
\hline $2021-2030$ & 999 & 766 & 1765 \\
\hline
\end{tabular}

By county, most vacancies (637 or about one third) were registered in the City of Zagreb, followed by 121 (6.4\%) in Zagreb County and 102 (5.6\%) in SplitDalmatia County. The lowest number of

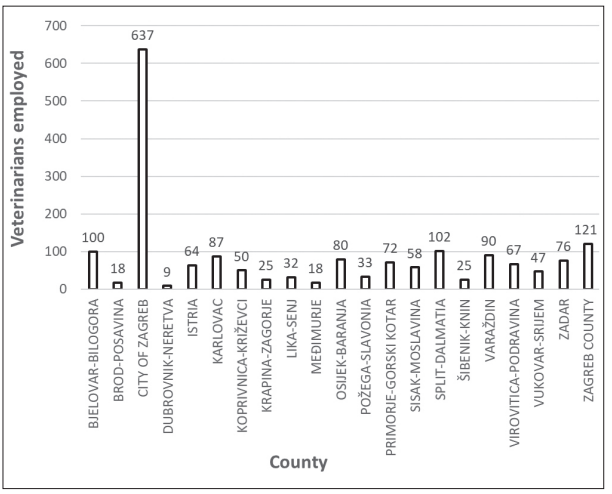

Fig. 10. Registered vacancies for veterinarians by county (2010-2019) (Source: CES - Croatian Employment Service, author's calculation]

vacancies, only 9 or $0.5 \%$, was recorded in Dubrovnik-Neretva County.

Vacancies for veterinarians were registered in 14 different groups of activities, mostly (51.5\%) in the activities of group $\mathrm{M}$ (professional, scientific and technical activities), followed by $14.4 \%$ in group G (wholesale and retail trade) and $11.1 \%$ in group P activities (education) (Fig. 11).

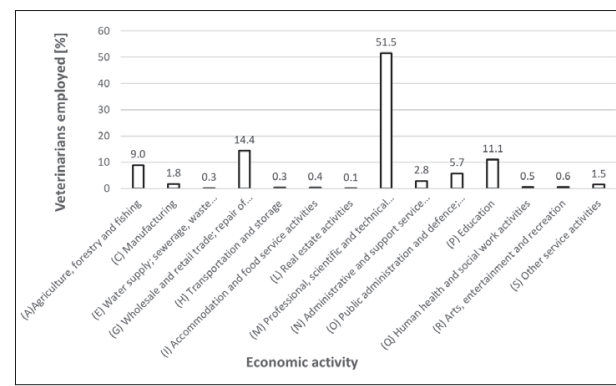

Fig. 11. Registered vacancies for veterinarians by the National Classification of All Economic Activities in the period 2010-2019 (NKD 2007) (Source: CES - Croatian Employment Service, author's calculation)

There are two types of employment: fixed-term and permanent. The majority of vacancies for veterinarians related to fixed-term employment (59.3\%). The proportion of realized fixed-term employment of veterinarians in the 
observed period $(78.1 \%)$ was significantly higher (18.8 percentage points or $31.7 \%$ ) than the proportion of all reported fixedterm vacancies (Fig. 12).

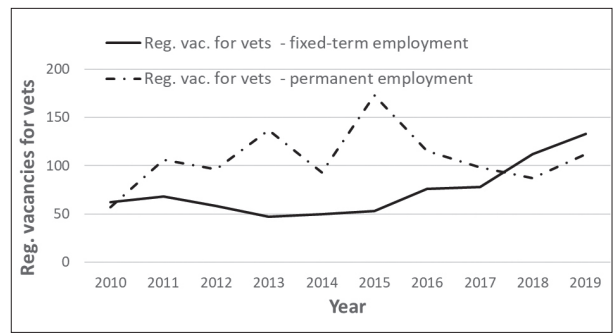

Fig. 12. Registered vacancies for veterinarians by type of employment (permanent or fixed-term) (Source: CES - Croatian Employment Service, author's calculation)

The projection of the Economic Institute for the Agriculture, Food and Veterinary Sector (Anonymous, 2016) shows that the number of employees in this sector will grow slowly from 2016 to 2020 but will not exceed the number from 2014 (Table 2). In veterinary activities, a stronger positive trend was expected, with a projected increase in the number of employees by 349 workers or $14.2 \%$ between 2014 and 2020. At the sector level, stagnation is predicted, though this does not apply to the veterinary subsector.

\section{Discussion}

The average number of employed veterinarians from 2010 to 2019 from the CES records was higher than the average number of unemployed veterinarians registered, indicating that demand for veterinarians surpassed supply.

Work experience is often an unavoidable criteria for employment, and as young people usually lack the necessary work experience, they encounter obstacles in their first employment. Veterinarians were employed faster than the average of those with a university degree, within 180 days of registering with the CES, and very few were in long-term unemployment (unemployed for more than one year). Most were employed under the age of 30, i.e. in the youth category. Veterinarians without work experience were employed most frequently, and more women than men were employed since more women enrol and graduate from the Faculty of Veterinary Medicine.

Veterinarians were mostly employed in the City of Zagreb, as the largest economic and administrative centre in Croatia. As there is a significant gap in the development of counties, the disparity in employment between the City of Zagreb and other parts of Croatia is high. This is also an indicator of the relatively low livestock production and depopulation of rural areas, which are traditionally the main and safest sources of employment for veterinarians (Tadić et al., 2009, 2016; Cvitković et al., 2020). Increased employment in rural areas would be a sign of increasing agricultural production and rural development.

According to the National Classification of Economic Activities (NKD), veterinarians were employed in 18 different groups of activities,

Table 2. Projection of the number of employees for Agriculture, Food and Veterinary Sector (by the Croatian Qualifications Framework - HKO) and for veterinary activities (by National Classification of All Economic Activities - NKD) (Anonymous, 2016)

\begin{tabular}{|l|c|c|c|c|c|c|c|}
\hline & 2014 & 2015 & 2016 & 2017 & 2018 & 2019 & 2020 \\
\hline $\begin{array}{l}\text { Agriculture, Food and } \\
\text { Veterinary Sector }\end{array}$ & 56,758 & 56,626 & 56,604 & 56,645 & 56,674 & 56,709 & 56,751 \\
\hline Veterinary activities & 2,105 & 2,299 & 2,327 & 2,362 & 2,393 & 2,424 & 2,454 \\
\hline
\end{tabular}


mostly in group M (professional, scientific and technical activities) and group G (wholesale and retail trade). It is important to point out that a larger number of activities in which workers are employed enables greater employment flexibility and greater mobility on the labour market. According to the National Classification of Occupations (NKZ), on the other hand, most veterinarians were employed in group 2 (experts and scientists), likely since veterinary medicine is a regulated profession. This also means that a small number of veterinarians were employed under their current qualification level.

When it comes to the type of employment (fixed-term or permanent), it should be noted that employment may exceptionally be contracted as fixed-term (for employment terminated by a deadline, execution of a certain job or occurrence of a certain event) (Official Gazette $93 / 14,127 / 17,98 / 19)$. The data show that the employment of veterinarians was relatively better than that of other university-educated workers due to the higher proportion of reported vacancies for permanent employment. Consequently, employment of veterinarians was permanent more often than for the average person with a university degree. Permanent employment is significantly better and more socially acceptable than fixed-term employment.

The number of registered vacancies mainly increased with minor oscillations. The regression equation showed that the number of jobs offered to veterinarians in the observed period grew by slightly more than 9 jobs on average per year, indicating a possible increase in the future demand for veterinarians. A similar conclusion could be made based on the projection of future trends on the labour market of the Institute of Economics in Zagreb, which shows that an increase in the number of employed veterinarians was expected in the period from 2014 to 2020 and that a significant number of current employees in veterinary activities are due to retire. Considering that veterinarians were mostly employed in the City of Zagreb and Zagreb County, this is where the most vacancies were registered.

The data imply that it is necessary to increase the number of veterinarians, but also to raise their level of competencies to respond to the increased competition on the European and global labour markets.

\section{References}

1. Anon. (2007): Joint Memorandum on Social Inclusion of the Republic of Croatia. (In Croatian).

2. Anon. (2015): Profile of the Agriculture, Food and Veterinary sector. Zagreb: Economic institute. (In Croatian).

3. Anon. (2016): Projection on future labor market developments. Zagreb: Economic institute. (In Croatian).

4. Anon. (2020a): https://statistika.hzz.hr/, 28.04.2020.

5. Anon. (2020b): https://www.dzs.hr/, 28.04.2020.

6. Anon. (2020c): https://hkosektor.poslovna.hr/, 28.04.2020.

7. Anon. (2020d): http://www.vef.unizg.hr/wp

8. content/uploads/2018/08/informacijski_ paket_2018-19-compressed.pdf, 09.05.2020.

9. CVETNIĆ, Ž. (2019): Diseases that changed the world. Zagreb: Medicinska naklada Zagreb, Croatian Veterinary Institute, Zagreb, Croatia. (In Croatian).

10. CVITKOVIĆ, D., M. TADIĆ, S. PAŠIĆ and M. PAVLAK (2020): Some business indicators of veterinary organizations in the light of general economic trends in Croatia. Vet. stn. 51, 155-162. (In Croatian).

11. DŽAJA, P. and K. SEVERIN (2019a): Historical overview of the global veterinary profession from the Middle Ages to the $19^{\text {th }}$ century, with special reference to the incidence of infectious diseases in domestic animals. Vet. stn. 50, 175-181. (In Croatian).

12. DŽAJA, P. and K. SEVERIN (2019b): Veterinary profession in Antiquity. Vet. stn. 50, 577-586. (In Croatian).

13. GREGURIĆ GRAČNER, G., N. LONČARIĆ, J. BUBIĆ ŠPOLJAR, A. DOVČ, K. FUŠ, D. GRAČNER and Ž. PAVIČIĆ (2019): 3R Principle for the welfare protection of animals used for scientific purposes yesterday, today, tomorrow. Vet. stn. 50, 63-73. (In Croatian).

14. MRAOVIĆ, J., B. JURIĆ, M. KRZNARIĆ, Z. TUS, M. LONČAR, V. VRKIĆ, A. MARINCULIĆ, K. KRIVIČIĆ and M. PAVLAK (2019): Epidemiological study of certain zoonoses in dogs and assesment of risk factors. Vet. stn. 50, 423-434. (In Croatian). 
15. OFFICIAL GAZETTE 105/2001: Methodology of the national standard classification of education. (In Croatian).

16. OFFICIAL GAZETTE 111/1998: National classification of occupations. (In Croatian).

17. OFFICIAL GAZETTE 118/2018: Labor Market Lawd. (In Croatian).

18. OFFICIAL GAZETTE 124/2014: Education, science and technology strategy. (In Croatian).

19. OFFICIAL GAZETTE 22/2013, 41/2016, 64/2018: Law on the Croatian Qualifications Framework consolidated text of the law. (In Croatian).

20. OFFICIAL GAZETTE 93/2014, 127/2017, 98/2019: Labor Law. (In Croatian).

21. OFFICIAL GAZETTE 98/1994: Law on National Classification of Economic Activities. (In Croatian).

22. TADIĆ, M. (2012): Consequences of the recession in Croatian veterinary medicine. Vet. stn. 43, 69-75. (In Croatian).

23. TADIĆ, M. and J. ŠIMIČIĆ (2006): Social reputation of the veterinary profession and the economic position of veterinary medicine in the Republic of Croatia. Vet. stn. 37, 15-23. (In Croatian).

24. TADIĆ, M., V. TADIĆ, D. CVITKOVIĆ, M. PAVLAK and V. ANIĆ (2009): Recession and veterinary practice. Vet. stn. 40, 337-351. (In Croatian).
25. TADIĆ, M., V. ANIĆ and A. GAŠPAR (2016): The End of Recession in Croatian Veterinary Medicine? Vet. stn. 47, 415-422. (In Croatian).

26. TADIĆ, M., V. ANIĆ and M. PAVLAK (2013): The Recession Period in Croatian Veterinary Medicine. Vet. stn. 44, 1-9. (In Croatian).

27. ZAVRTNIK, S. and D. ŽUBČIĆ (2017a): The historical, biblical, cultural and social foundations of Hebrew veterinary and human medicine. Vet. stn. 48, 235-247. (In Croatian).

28. ZAVRTNIK, S. and D. ŽUBČIĆ (2017b): Old Testament prophylaxis regulation of Hebrew veterinary and human medicine. Vet. stn. 48, 327335. (In Croatian).

29. ZAVRTNIK, S. and D. ŽUBČIĆ (2017c): Animal cleanliness and sacrifice by the early Hebrews. Vet. stn. 48, 399-409. (In Croatian).

30. ZAVRTNIK, S. and D. ŽUBČIĆ (2017d): Ethical principles in the relationship between man, animals and nature among the early Hebrews. Vet. stn. 48, 477-480. (In Croatian).

31. ZAVRTNIK, S. and D. ŽUBČIĆ (2018): An overview of the historical and biblical beginnings of veterinary and human medicine in the culture and society of the early Hebrews. Vet. stn. 49, 203-219. (In Croatian).

\section{Zapošljavanje doktora veterinarske medicine u razdoblju od 2010. - 2019.}

Dr. sc. Denis CVITKOVIĆ, dr. med. vet., docent, Veterinarski fakultet Sveučilišta u Zagrebu, Hrvatska; Boris VOLAREVIĆ, prof., Hrvatski zavod za zapošljavanje, RO Sisak, Sisak, Hrvatska; dr. sc. Marko TADIĆ, dr. med. vet., redoviti profesor u mirovini; dr. sc. Selim PAŠIĆ, dipl. ing. fiz., docent, dr. sc. Marina PAVLAK, dr. med. vet., redovita profesorica, Veterinarski fakultet Sveučilišta u Zagrebu, Hrvatska

Zapošljavanje veterinara jedan je od pokazatelja smjera razvoja gospodarstva i kvalitete odnosa čovjeka i prirode od koje živi. O zaposlenosti veterinara već su u nekoliko navrata pisali neki autori. U ovome radu željeli smo ustvrditi kakva su kretanja nezaposlenosti i zapošljavanja veterinara prema podatcima iz evidencije Hrvatskog zavoda za zapošljavanje (HZZ) u razdoblju od 2010. - 2019. HZZ je javna ustanova u vlasništvu Republike Hrvatske ustrojena Zakonom o tržištu rada (Narodne novine 118/2018) i ima ključnu ulogu u reguliranju ponude i potražnje na tržištu rada Republike Hrvatske. Prosječan broj zapošljavanih veterinara bio je veći od prosječnog broja veterinara registriranih u evidenciji HHZ-a. Godišnje je prosječno tražen 181 veterinar, zapošljavano ih je 160, a prijavljivano 143. Potražnja za veterinarima bila je veća od ponude. Veterinari su se zapošljavali brže od prosjeka zapošljavanja osoba s fakultetskom diplomom, većinom $\mathrm{u}$ roku do 180 dana te ih je vrlo mali broj bio u dugotrajnoj nezaposlenosti. Najviše ih je zapošljavano u kategoriji mladih (do 30 godina), a najviše su se zapošljavali oni bez radnog staža. Zapošljavano je više žena nego muškaraca. Najviše ih je zapošljavano u Gradu Zagrebu, što je istovremeno odraz razmjerno niske stočarske proizvodnje i depopulacije ruralnih područja koja su tradicionalno glavni i najsigurniji izvor zapošljavanja za veterinare. Prema Nacionalnoj klasifikaciji djelatnosti (NKD) veterinari su se zapošljavali u gotovo svim skupinama djelatnosti što im omogućava veću fleksibilnost zapošljavanja i veću mobilnost na tržištu rada. Prema Nacionalnoj klasifikaciji zanimanja (NKZ), 
najviše se veterinara zapošljavalo $\mathrm{u}$ rodu 2 (stručnjaci i znanstvenici), vjerojatno zato što je veterinarstvo regulirana profesija. To istovremeno znači da ih se mali broj zapošljavao na razinama obrazovanja nižima od stečene. Zapošljavanje veterinara bilo je razmjerno kvalitetnije nego $u$ drugih fakultetski obrazovanih radnika zbog razmjerno većeg udjela prijavljenih slobodnih radnih mjesta na neodređeno vrijeme. Regresijska jednadžba pokazala je da je broj ponuđenih radnih mjesta za veterinare u promatranom razdoblju rastao za nešto više od 9 radnih mjesta godišnje što upućuje na moguće povećanje potražnje za veterinarima $u$ budućem razdoblju. Isti trend vidljiv je i iz projekcije budućih kretanja na tržištu rada koja je predviđala porast broja zaposlenih veterinara $\mathrm{u}$ razdoblju od 2014. do 2020. te povećani broj odlazaka u mirovinu. Svi ovi podatci pokazuju da je potrebno povećati broj veterinara, ali isto tako i podizati razinu njihovih kompetencija zbog povećavanja konkurencije na europskom i svjetskom tržištu rada.

Ključne riječi: tržište rada, veterinari, povećano zapošljavanje 